\title{
BIOCHARCOAL DARI KULIT RAMBUTAN (NEPHELIUM LAPPACEUM L.) SEBAGAI ADSORBEN ZINK DAN TEMBAGA
}

\author{
Biocharcoal from Rambutan (Nephelium lappaceum L.) Peel as an Adsorbent of Zinc and Copper
}

\author{
*I Ketut Ardi Setiawan, Mery Napitupulu, dan Daud K. Walanda
}

Pendidikan Kimia/FKIP - Universitas Tadulako, Palu - Indonesia 94118

Received 03 December 2016, Revised 08 January 2017, Accepted 14 February 2017

\begin{abstract}
Rambutan peel is one source of biocharcoal production to adsorb metal ions because of the potential of cellulose content. This study aimed to describe the characteristics of biocharcoal from rambutan peel as well as to determine biocharcoal adsorption to zinc and copper based on the variation of biocharcoal weight and metal ions concentrations. The method used in this study was a laboratory experiment, and metals were analyzed using spectrophotometer spectroDirect. The results showed the moisture and ash levels of the biocharcoal were $0.4 \%$ and $5.4 \%$, respectively. The optimum weight of biocharcoal to adsorb $\mathrm{Zn}$ and $\mathrm{Cu}$ ions was $40 \mathrm{mg}$ with their percentage adsorption of $98.81 \%$ and $98.94 \%$, respectively. The optimum concentration adsorption of biocharcoal to $\mathrm{Zn}$ ions was $40 \mathrm{ppm}$ with the percentage adsorption of $98.32 \%$, while for the Cu ions was $60 \mathrm{ppm}$ with the percentage adsorption of $98.25 \%$.
\end{abstract}

Keywords: Biocharcoal, rambutan peel, adsorption, zinc, copper, spectrophotometer, spectroDirect.

\section{Pendahuluan}

Pembangunan di dalam negeri memberikan pengaruh positif berupa meningkatnya kesejahteraan masyarakat Indonesia. Namun demikian, pembangunan ini dapat membawa efek negatif yaitu menurunnya kualitas lingkungan akibat limbah yang dihasilkan dari kegiatan industri maupun limbah rumah tangga dari kegiatan pembangunan tersebut. Limbah-limbah yang beracun pada umumnya merupakan limbah kimia, baik itu berupa persenyawaan atau hanya dalam bentuk unsur atau ion. Biasanya senyawa kimia yang beracun bagi organisme hidup dan manusia adalah senyawasenyawa kimia yang mempunyai bahan aktif dari logam-logam berat (Marlinawati dkk., 2015).

Logam berat merupakan logam yang berbahaya sebagai zat pencemar, seperti timbal (Pb), kadmium $(\mathrm{Cd})$, kromium $(\mathrm{Cr})$, besi $(\mathrm{Fe})$, zink ( $\mathrm{Zn})$ dan merkuri $(\mathrm{Hg})$. Logam berat ini umumnya dapat tersalurkan dalam berbagai macam perantara, seperti udara, air, tanah, maupun makanan yang terkontaminasi oleh logam berat. Logam-logam ini juga dapat terakumulasi dalam tubuh dan masuk dalam rantai makanan, sehingga pada tingkat akumulasi logam yang tinggi dapat mengakibatkan keracunan yang pada tingkat kroni menyebabkan kematian (Diantariani, 2006).

Logam berat masuk ke dalam jaringan tubuh makhluk hidup melalui beberapa rute, yaitu saluran pernapasan, pencernaan, dan penetrasi melalui kulit. Adsorpsi logam melalui saluran pernapasan cukup besar, baik pada biota air yang masuk melalui sistem pernapasan, maupun biota darat yang masuk melalui

${ }^{*}$ Correspondence:

I Ketut Ardi Setiawan

Program Studi Pendidikan Kimia, Fakultas keguruan dan IImu Pendidikan, Universitas Tadulako

e-mail: iketutardisetiawan02@gmail.com

Published by Universitas Tadulako 2018 debu di udara ke saluran pernapasan. Efek toksik dari logam berat mampu menghalangi kerja enzim sehingga mengganggu metabolisme tubuh, menyebabkan alergi, bersifat mutagen, dan karsinogen bagi tubuh manusia maupun hewan (Widowati dkk., 2008).

Logam tembaga merupakan logam esensial dan diperlukan dalam kelangsungan hidup organisme. Manfaat logam tembaga bagi setiap organisme tersebut bervariasi, dan jika kadar dari logam ini melebihi dari batas yang telah ditentukan maka logam ini dapat menimbulkan dampak yang negatif bagi individu tersebut. Bagi manusia gejala yang timbul dari keracunan akut $\mathrm{Cu}$ yaitu mual, muntah-muntah, diare, sakit perut hebat, hemolisis darah, kejang dan akhirnya dapat menyebabkan kematian (Darmono, 1995).

Zink diperlukan dalam tubuh manusia, dimana logam ini berperan pada sistem kekebalan, penyembuhan luka, dan mengatasi diare (Herwana dkk., 2006). Namun zink mempunyai dampak negatif bagi kesehatan terutama jika kadarnya sudah melebihi batas kadar yang dibutuhkan oleh tubuh. Walaupun pada konsentrasi rendah, efek ion logam berat dapat berpengaruh langsung hingga terakumulasi pada rantai makanan. Zink di alam tidak berada dalam keadaan bebas, tetapi dalam bentuk persenyawaan dengan unsur lain berupa mineral (Darmayanti dkk., 2012).

Metode yang dapat digunakan untuk menurunkan konsentrasi ion logam berat dalam limbah cair diantaranya adalah adsorpsi menggunakan biomassa (Ni'mah \& Ulfin, 2007), penggunaan tanaman air (Suryati \& Priyanto, 2003) dan dengan cara penjerapan bahan pencemar oleh adsorben berupa karbon aktif (Gaya dkk., 2015). Penghilangan logam berat dari lingkungan tercemar pada umumnya seringkali menggunakan metode adsorpsi. Penggunaan metode ini dilakukan dengan proses yang sederhana serta bahan yang digunakan tidak terlalu 
sulit untuk diperoleh sehingga adsorpsi merupakan metode yang relatif sederhana (Marlinawati dkk., 2015).

Teknik adsorpsi terhadap logam berat telah banyak dilakukan dengan menggunakan berbagai macam adsorben, diantaranya adsorben menggunakan biocharcoal. Penelitian sebelumnya dilakukan pemanfaatan biocharcoal dari kulit pisang kepok sebagai penjerap ion timbal dan zink (Rudin, 2011), batang pisang sebagai penjerap ion kromium (Widihati dkk., 2012), kulit durian sebagai penjerap ion cadmium (Napitupulu, dkk., 2018), biji salak sebagai penjerap ion kromium (Pongenda dkk., 2015), kulit kakao sebagai penjerap ion timbal (Podala dkk., 2015), serbuk gergaji kayu cempaka sebagai penjerap zink dan tembaga (Susilawati dkk., 2015).

Biocharcoal merupakan padatan yang dapat berbentuk serbuk dan butiran yang merupakan suatu senyawa karbon yang mempunyai ciri-ciri khas berupa permukaan pori yang luas dan dalam jumlah yang banyak. Bahan baku pembuatan biocharcoal umumnya adalah residu biomasa pertanian atau kehutanan, termasuk potongan kayu, tempurung kelapa, kulit-kulit kayu, serta bahan organik yang berasal dari sampah kertas, sampah kota dan kotoran hewan (Gani, 2010). Pembuatan biocharcoal umumnya sangat sederhana karena bahan dasarnya mudah ditemukan dimana salah satunya seperti kulit rambutan.

Rambutan (nephelium lappaceum L.) merupakan salah satu komoditas buah tropis yang digemari oleh masyarakat, baik dalam negeri maupun luar negeri. Konsumsi rambutan di Kecamatan Poso Pesisir Utara termasuk dalam tingkatan yang cukup tinggi, sehingga kemungkinan menghasilkan kulit rambutan dalam jumlah yang besar, yang pada akhirnya menjadi limbah. Limbah tersebut jika dibiarkan begitu saja akan mengganggu kebersihan lingkungan yang dapat menyebabkan timbulnya sarang penyakit dan jika dibakar akan menimbulkan pencemaran udara.

Dari karakteristik yang dimiliknya, kulit rambutan memiliki senyawa kimia yang cukup beragam seperti, antosianin, flavonoid, tanin, dan saponin (Hanum, 2008). Kulit rambutan juga mengandung lignin 35\% dan selulosa 24\% (Oliveira dkk., 2016). Keberadaan senyawa kimia ini menjadikan kulit rambutan sebagai bahan baku yang potensial untuk pembuatan biocharcoal. Jika kulit rambutan mengalami pembakaran tidak sempurna maka akan dapat menghasilkan karbon yang cukup besar.

Artikel ini dimaksudkan untuk mendeskripsikan karakteristik biocharcoal dari kulit rambutan; berat optimum biocharcoal terhadap adsorpsinya pada zink dan tembaga; dan konsentrasi optimum zink dan tembaga dalam larutan terhadap adsorpsi biocharcoal.

\section{Metode}

Alat utama yang digunakan yaitu Spektrofotometer spektroDirect (Lovibond), tanur, shaker dan $\mathrm{pH}$ meter. Sedangkan bahan yang digunakan yaitu biocharcoal kulit rambutan, aquades, serbuk $\mathrm{ZnSO}_{4} 7 \mathrm{H}_{2} \mathrm{O}$ (Merck), serbuk $\mathrm{CuSO}_{4}-5 \mathrm{H}_{2} \mathrm{O}$ (Merck), larutan $\mathrm{HCl}$ (Merck), dan kertas saring Whatman 41.

\section{Pembuatan biocharcoal kulit rambutan}

Kulit rambutan bersih dikeringkan di bawah paparan sinar matahari selama \pm 5 hari. Sampel kulit rambutan yang telah kering dimasukan ke dalam tanur. Sampel tersebut dibakar (pirolisis) pada suhu $350{ }^{\circ} \mathrm{C}$. Setelah menjadi arang, sampel didiamkan sampai dingin. Biocharcoal dihaluskan dengan menggunakan lumpang dan alu, setelah itu diayak dengan ayakan 200 mesh.

\section{Karakteristik Biocharcoal kulit rambutan}

Biocharcoal ditimbang dengan teliti sebanyak 5 gram di dalam cawan porselin yang telah diketahui beratnya dan telah dipanaskan sebelumnya sampai berat konstan. Kemudian dipanaskan dalam oven pada temperatur $105^{\circ} \mathrm{C}$ selama kurang lebih 3 jam. Setelah itu didinginkan dalam desikator dan ditimbang. Perlakuan yang sama diulangi sampai diperoleh berat konstan.

Biocharcoal ditimbang dengan teliti sebanyak 5 gram dalam cawan yang telah diketahui beratnya dan telah dipanaskan sebelumnya sampai berat konstan. Kemudian diabukan dalam tanur pada temperatur $700{ }^{\circ} \mathrm{C}$ selama 3 jam. Setelah itu didinginkan dalam desikator dan ditimbang. Perlakuan yang sama diulangi sampai diperoleh bobot yang tetap.

\section{Pengaruh berat biocharcoal}

Biocharcoal masing-masing dengan berat 20 , 40, 60, 80 dan $100 \mathrm{mg}$ dimasukan dalam 5 buah Erlenmeyer dibuat dalam dua deret. Deret pertama ditambahkan $25 \mathrm{~mL}$ larutan zink $100 \mathrm{ppm}$ pada $\mathrm{pH}$ 6 dengan penambahan larutan $\mathrm{HCl}$. Deret kedua ditambahkan $25 \mathrm{~mL}$ larutan tembaga $100 \mathrm{ppm}$. Erlenmeyer kemudian ditutup dengan aluminium foil dan dikocok menggunakan shaker selama 1 jam. Filtrat dan residu dipisahkan dengan penyaringan menggunakan kertas saring Whatman 41. Konsentrasi larutan filtrat diukur menggunakan spektrofometer spektroDirect.

\section{Pengaruh konsentrasi larutan zink dan tembaga}

Larutan zink dan tembaga dibuat sebanyak $25 \mathrm{~mL}$ dengan konsentrasi berturut-turut 20, 40, 60, 80 dan 100 ppm. Larutan zink pada pH 6 dengan penambahan larutan $\mathrm{HCl}$. Masing-masing larutan tersebut ditambahkan biocharcoal dengan berat optimum yang diperoleh pada langkah sebelumnya. Erlenmeyer ditutup menggunakan aluminium foil dan selanjutnya dikocok menggunakan shaker selama 1 jam. Filtrat dan residu dipisahkan dengan penyaringan menggunakan kertas saring Whatman 41. Konsentrasi larutan filtrat diukur menggunakan spektrofometer spektroDirect. 


\section{Analisis data}

Untuk menganalisa persentase adsorpsi menggunakan persamaan sebagai berikut: $\mathrm{C}_{b}=\mathrm{C}_{\mathrm{i}}-\mathrm{C}_{\mathrm{eq}}$ dan $\% \mathrm{Zn}$ dan $\mathrm{Cu}=\mathrm{C}_{\mathrm{b}} / \mathrm{C}_{\mathrm{i}} \mathrm{x} 100 \%$; dimana, $\mathrm{C}_{\mathrm{b}}$ adalah konsentrasi $\mathrm{Zn} / \mathrm{Cu}$ yang terjerap $(\mathrm{mg} / \mathrm{L}) ; \mathrm{C}_{\mathrm{i}}$ adalah konsentrasi $\mathrm{Zn} / \mathrm{Cu}$ mula-mula (mg/L); dan $\mathrm{C}_{\text {eq }}$ adalah konsentrasi $\mathrm{Zn} / \mathrm{Cu}$ saat kesetimbangan (mg/L) (Gaya dkk., 2015).

\section{Hasil dan Pembahasan}

\section{Kadar air}

Penentuan kadar air bertujuan untuk mengetahui sifat hidrokopis dari biocharcoal kulit rambutan. Kadar air biocharchoal dari kulit rambutan diperoleh $0,4 \%$. Kadar air dari hasil penelitian ini relatif kecil, dan ini menunjukkan bahwa kandungan air yang terdapat dalam sampel telah menguap selama proses karbonisasi berlangsung.

Berdasarkan nilai kadar air biocharcoal yang diperoleh, dapat diketahui bahwa biocharcoal kulit rambutan bersifat higroskopis dan memiliki kemampuan untuk mengadsorpsi gas atau cairan lain. $\mathrm{Hal}$ ini disebabkan karena biocharcoal memiliki poripori atau luas permukaan yang besar (Mutmainnah, 2012). Semakin kecil kadar air yang dimiliki, kualitas biocharcoal makin baik. Apabila pori-pori biocharcoal mengandung air maka akan mengganggu interaksi ion logam terhadap pusat aktif biocharcoal, sebab air akan menutupi pori-pori biocharcoal serta akan berkompetisi dengan absorben untuk mengikat logam (Talunoe, 2014). Selain itu, biocharcoal sebagian besar terdiri dari unsur karbon bebas dan masingmasing berikatan secara kovalen.

\section{Kadar $a b u$}

Penetapan kadar abu biocharcoal dilakukan untuk mengetahui kandungan oksida logam dalam biocharcoal. Abu merupakan oksida-oksida logam dalam biocharcoal yang terdiri dari mineral yang tidak dapat menguap (non volatile) pada proses pengabuan. Tinggi rendahnya kadar abu yang dihasilkan dapat mempengaruhi daya adsorpsi biocharcoal. Semakin tinggi kadar abu, maka daya adsorpsi biocharcoal semakin lemah. Hal ini disebabkan karena keberadaan abu yang berlebihan dapat menyebabkan penyumbatan pori-pori pada biocharcoal sehingga luas permukaan biocharcoal semakin berkurang (Junary dkk., 2015). Dimana penyumbatan terjadi karena pori-pori biocharcoal terisi oleh mineralmineral logam seperti $\mathrm{K}, \mathrm{Na}, \mathrm{Ca}$, dan $\mathrm{Mg}$ (Lebu, 2009).

Biocharcoal kulit rambutan yang dihasilkan pada penelitian ini memiliki kadar abu sebesar 5,4\%. Hasil yang diperoleh menunjukkan bahwa kadar abu yang terdapat pada biocharcoal relatif rendah. Hal ini menandakan bahwa tidak terjadi penyumbatan pada pori-pori biocharcoal yang mengakibatkan luas permukaan biocharcoal menjadi berkurang (Feng dkk., 2014).

Berdasarkan data tersebut biocharcoal kulit rambutan memiliki kadar air sebesar $0,4 \%$ dan kadar abu sebesar 5,4\%, maka dalam biocharchoal mengandung 94,2\% karbon dan senyawa lain yang dapat menjerap logam. Sebanyak 5 gram bicharcoal mengandung 0,29 gram air dan abu, sehingga tersisa 4,71 gram biomassa yang dapat menjerap ion logam.

\section{Variasi Berat Biocharcoal terhadap Adsorpsi Zink dan Tembaga}

Biocharcoal kulit rambutan pada penelitian ini bertidak sebagai adsorben, dimana adsorben merupakan faktor yang sangat mempengaruhi proses adsorpsi ion $\mathrm{Zn}$ dan $\mathrm{Cu}$ dalam larutan. Hal ini disebabkan karena berat biocharcoal menunjukan jumlah partikel adsorben yang dapat menyerap ion logam berat pada konsentrasi tertentu. Penentuan berat optimum biocharcoal untuk adsorpsi ion $\mathrm{Zn}$ dan $\mathrm{Cu}$ dilakukan pada 5 variasi berat biocharcoal yaitu 20, 40, 60, 80 dan $100 \mathrm{mg}$. Penentuan berat optimum ini dilakukan dalam larutan dengan konsentrasi 100 ppm.

Berdasarkan data yang disajikan pada Gambar 1 yaitu menunjukkan penyerapan ion $\mathrm{Zn}$ (biru) dan $\mathrm{Cu}$ (merah) dipengaruhi oleh berat adsorben.

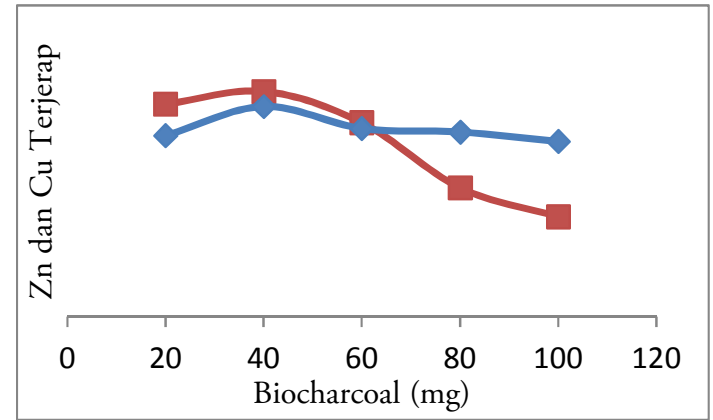

Gambar 1. Kurva hubungan antara berat biocharcoal $(\mathrm{mg})$ terhadap persen ion $\mathrm{Zn}(\bullet)$ dan $\mathrm{Cu}(\bullet)$ terjerap

Data yang diperoleh untuk ion $\mathrm{Zn}$ dan $\mathrm{Cu}$ menunjukan penjerapan meningkat dari $20 \mathrm{mg}$ dan $40 \mathrm{mg}$, namum penjerapan ion logam menurun dari 60, 80 dan $100 \mathrm{mg}$.

Penggunaan waktu kontak 60 menit didasarkan pada penelitian yang dilakukan oleh (Pongenda dkk., 2015) mengenai waktu kontak optimum biocharcoal, diperoleh waktu kontak optimum biocharcoal 60 menit. Penggunaan $\mathrm{pH} 5$ pada larutan tembaga didasarkan pada penelitian (Tong dkk., 2011) mengenai penentuan $\mathrm{pH}$ optimum tembaga, hasil yang diperoleh $\mathrm{pH}$ optimum tembaga yaitu 5. Penggunaan pH 6 pada larutan zink didasarkan penelitian (Darmayanti dkk., 2012) mengenai penentuan $\mathrm{pH}$ optimum zink. Hasil yang diperoleh jika $\mathrm{pH}<6$ maka tingkat keasaaman larutan akan tinggi sehingga menyebabkan banyak ion $\mathrm{H}+$ pada larutan yang akan mencegah interaksi ion logam dan biocharcoal sedangkan $\mathrm{pH}>6$ ion $\mathrm{Zn}$ telah mengendap sebagai hidroksidanya yaitu $\mathrm{Zn}(\mathrm{OH})_{2}$.

Meningkatnya massa biocharcoal kulit rambutan 20 $\mathrm{mg}$ dan $40 \mathrm{mg}$ sebanding dengan meningkatnya jumlah partikel dan luas permukaan biocharcoal. Semakin banyak massa biocharchoal maka akan semakin banyak biocharcoal yang berinteraksi dengan 
ion logam (Wahyuni dkk., 2015). Semakin bertambahnya interaksi biocharcoal dengan ion logam akan membuat semakin banyaknya ion zink dan tembaga yang terjerap. Dimana bertambahnya sisi aktif adsorpsi dan efesiensi penjerapannya pun meningkat dengan bertambahnya massa adsorben (Apriliani, 2010).

Peningkatan penjerapan akan terus bertambah dengan adanya pertambahan berat biocharcoal sampai pada batasan berat tertentu. Hal ini juga menyatakan bahwa pada saat peningkatan massa adsorben, maka mengakibatkan peningkatan persentase efisiensi penjerapan dan penurunan kapasitas penjerapan (Barros dkk., 2003). Proses adsorpsi berlangsung pada lapisan permukaan adsorben, dimana pada adsorben mempunyai situs-situs yang bermuatan berlawanan dengan muatan ion logam sehingga interaksi pasif dan relatif cepat. Partikel dari adsorben memiliki sisi aktif yang bermuatan negatif yang berinteraksi dengan ion logam yang bermuatan positif (Mahvi dkk., 2005).

Peningkatan adsorpsi meningkat dengan adanya peningkatan jumlah adsorben samapai pada titik jenuh. Jerapan ion $\mathrm{Zn}$ dan $\mathrm{Cu}$ cenderung menurun pada berat biocharcoal $60 \mathrm{mg}, 80 \mathrm{mg}$ dan $100 \mathrm{mg}$. Penurunan adsorpsi secara perlahan pada tingkat berat yang lebih tinggi menunjukan adanya tumpang tindih atau pengumpulan dari situs-situs adsorpsi, sehingga menyebabkan penurunan area permukaan adsorben dalam menjerap ion logam (Kili dkk., 2013). Selain itu, dapat terjadi karena permukaan adsorben sudah dalam keadaan jenuh dengan ion-ion $\mathrm{Zn}$ dan $\mathrm{Cu}$, sehingga peningkatan berat adsorben relatif tidak lagi mempengaruhi peningkatkan penjerapan ion logam oleh adsorben (Rudin, 2011). Berdasarkan data di atas maka dapat diketahui berat optimum biocharcoal untuk menjerap kedua ion $\mathrm{Zn}$ dan $\mathrm{Cu}$ yaitu $40 \mathrm{mg}$, dimana persentase untuk ion $\mathrm{Zn}$ yaitu 98,81\%, sedangkan untuk ion $\mathrm{Cu}$ yaitu $98,94 \%$.

\section{Variasi konsentrasi larutan terhadap adsorpsi zink dan tembaga}

Kemampuan penyerapan suatu adsorben juga dipengaruhi oleh konsentrasi dari larutan ion logam tersebut. Perbedaan konsentrasi akan mempengaruhi jumlah partikel-partikel yang terdapat dalam larutannya. Semakin besar konsentrasi suatu larutan, maka semakin banyak pula partikel-partikel yang terkandung di dalamnya dan akan mempengaruhi proses adsorpsi (Wahyuni dkk., 2015).

Pada penentuan konsentrasi larutan optimum terhadap adsorpsi zink dan tembaga oleh adsorben biocharcoal kulit rambutan dilakukan pada variasi konsentrasi 20, 40, 60, 80 dan 100 ppm. Penentuan konsentrasi larutan optimum ini bertujuan untuk mengetahui konsentrasi larutan optimum terhadap adsorpsi ion zink dan tembaga oleh adsorben biocharcoal. Berat adsorben yang digunakan yaitu berat optimum yang diperoleh dari variasi berat biocharchoal dimana masing-masing untuk logam $\mathrm{Zn}$ dan $\mathrm{Cu}$ yaitu $40 \mathrm{mg}$ adsorben.
Berdasarkan data yang disajikan pada Gambar 2 yaitu menunjukkan penjerapan ion $\mathrm{Zn}$ (biru) dan $\mathrm{Cu}$ (merah) dipengaruhi oleh konsentrasi larutan.

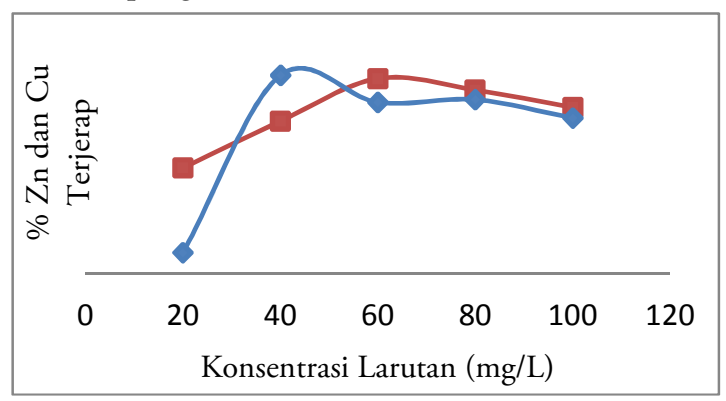

Gambar 2. Kurva hubungan antara konsentrasi larutan terhadap persen ion $\mathrm{Zn}(\bullet)$ dan $\mathrm{Cu}(\boldsymbol{\bullet})$ terjerap

Data yang diperoleh menunjukan terjadinya peningkatan presentasi jerapan ion $\mathrm{Zn}$ pada konsentrasi $20 \mathrm{ppm}$ dan $40 \mathrm{ppm}$, namun pada konsentrasi $60 \mathrm{ppm}$ mengalami penurunan penjerapan. Pada konsentrasi 80 ppm mengalami kenaikan penjerapan, namun tidak melebihi penjerapan pada konsentrasi $40 \mathrm{ppm}$. Selanjutnya pada konsentrasi 100 ppm mengalami penurunan persentasi penjerapan. Untuk ion $\mathrm{Cu}$ terjadi peningkatan jerapan dari konsentrasi 20, 40 dan 60 ppm. Namun pada konsentrasi 80 ppm dan 100 ppm mengalami penurunan jerapan.

Jerapan dipengaruhi oleh konsentrasi larutan, semakin besar konsentrasi larutan maka jerapan ion $\mathrm{Zn}$ dan $\mathrm{Cu}$ juga akan semakin bertambah sampai batas konsentrasi tertentu. Dalam hal ini adsorben belum jenuh dengan zat terjerap yaitu ion $\mathrm{Zn}$ dan $\mathrm{Cu}$ maka dengan memperbesar konsentrasi ion logam $\mathrm{Zn}$ dan $\mathrm{Cu}$ jumlah ion logam yang terjerap akan meningkat secara linear. Selanjutnya jika pusat aktif telah jenuh dengan ion logam maka peningkatan konsentrasi ion logam relatif tidak meningkatkan penjerapan ion logam oleh adsorben (Rudin, 2011).

Dengan meningkatnya konsentrasi ion logam, maka efesiensi penjerapan semakin berkurang. Hal ini disebabkan pada konsentrasi yang lebih tinggi, jumlah ion logam dalam larutan tidak sebanding dengan jumlah partikel biocharcoal yang tersedia sehingga permukaan biocharcoal akan mencapai titik jenuh dan kemungkinan akan terjadi proses desorpsi atau pelepasan kembali antara adsorben dengan adsorbat (Pongenda dkk., 2015). Jika konsentrasi dinaikan menyebabkan terjadinya peningkatan jumlah ion yang terikat pada adsorben sehingga nilai kapasitas penjerapan meningkat (Apriliani, 2010).

Berdasarkan data di atas maka dapat diketahui konsentrasi larutan optimum untuk ion $\mathrm{Zn}$ yaitu 40 ppm dan ion $\mathrm{Cu}$ yaitu 60 ppm. Persentase jerapan untuk ion $\mathrm{Zn}$ yaitu 98,32\% sedangkan untuk ion $\mathrm{Cu}$ yaitu $98,25 \%$.

\section{Kesimpulan}

Karakteristik biocharcoal kulit rambutan varietas binjai yang berasal dari Desa Trimulya, Kecamatan Poso Pesisir Utara, Kabupaten Poso, 
Sulawesi Tengah memiliki kadar air sebesar 0,4\% dan kadar abu biocharcoal sebesar 5,4\%. Berat optimum biocharcoal kulit rambutan untuk menjerap kedua ion $\mathrm{Zn}$ dan $\mathrm{Cu}$ adalah sebesar $40 \mathrm{mg}$, dengan persentase jerapan $98,81 \%$ dan $98,94 \%$. Daya adsorpsi optimum pada variasi konsentrasi larutan untuk ion $\mathrm{Zn}$ yaitu pada konsentrasi $40 \mathrm{ppm}$ dengan persentase jerapan $98,32 \%$ dan untuk ion logam $\mathrm{Cu}$ yaitu pada konsentrasi $60 \mathrm{ppm}$ dengan persentase jerapan $98,25 \%$.

\section{Ucapan Terima kasih}

Penulis mengucapkan terima kasih yang sebesar-besarnya kepada pihak-pihak yang telah membantu dalam melakukan penelitian ini, khususnya kepada kepada Tasrik selaku laboran Laboratorium FKIP Universitas Tadulako.

\section{Referensi}

Apriliani, A. (2010). Manfaat arang aktif dari ampas tebu untuk menyerap ion logam $\mathrm{Cd}, \mathrm{Cr}, \mathrm{Cu}$ dan $\mathrm{Pb}$ dalam air limbah. Jakarta: Universitas Indonesia Islam Negeri Syarif Hidayatullah.

Barros, J. L., Macedo, G. R., Duarte, M. M., Silvia, E. P., \& Lobato. (2003). Biosorpstion cadmium using the fungus aspergillus niger. Brazilian Journal of Chemical Engineering, 20(3), 1-17.

Darmayanti, Rahman, N., \& Supriadi. (2012). Adsorpsi timbal $(\mathrm{Pb})$ dan zink $(\mathrm{Zn})$ dari larutannya menggunakan arang hayati (biocharcoal) kulit pisang kepok berdasarkan variasi pH. Jurnal Akademika Kimia, 1(4), 159165.

Darmono. (1995). Logam dalam sistem biologi mabluk hidup. Jakarta: Universitas Indonesia Press.

Diantariani, N. (2006). Penentuan kandungan logam $p b$ dan or pada air sedimen di sungai ao desa samsam kabupaten Tabanan. Denpasar: Universitas Udayana.

Feng, Y., Yang, W., \& Chu, W. (2014). Contribution of Ash Content Related to Methane Adsorption Behaviors of Bituminous Coals. from https://www.hindawi.com/journals/ijce/2014/956 $543 /$

Gani, A. (2010). Multiguna arang-hayati biochar: SINAR TANI Edisi 13 - 19 Oktober 2010.

Gaya, U. I., Otene, E., \& Abdullah, A. H. (2015). Adsorption of aqueous $\mathrm{Cd}(\mathrm{II})$ and $\mathrm{Pb}$ (II) on activated carbon nanopores prepared by chemical activation of doum palm shell. SpringerPlus, 4(1), 458-476.

Hanum, C. (2008). Teknik budidaya tanaman Jilid 2. Jakarta: Direktorat Pembinaan Sekolah Menengah Kejuruan.

Herwana, E., Surjawidjaja, J. E., Lesmana, M., \& Hidayat, A. (2006). Efek hambatan zink sulfat terhadap pertumbuhan Shigella spp. Universa Medicina, 25(1), 1-6.
Junary, E., Pane, P. J., \& Herlina, N. (2015). Pengaruh suhu dan waktu kontak karbonisasi terhadap nilai kalor dan karakteristik pada pembuatan bioarang berbahan baku pelepah aren (Arenga pinnata). Jurnal Teknik Kimia USU, 4(2), 46-52.

Kili , M., Kirbiyik, ., epelio ullar, ., \& Pütűn, A. E. (2013). Adsorption of heavy metal ions from aqueous solutions by bio-char, a by-product of pyrolysis. Applied Surface Science, 283 (2013), 856-862.

Lebu, M. (2009). Pembuatan arang aktif dari tulang sapi dan aplikasinya pada pemucatan crude palm oil (CPU). Skripsi Sarjana Palu: Universitas Tadulako.

Mahvi, A., Naghipour, D., Vaezi, F., \& Nazmara, S. (2005). Teawaste As An Adsorbent For Heavy Metal Removal From Industrial Wastewater. American Journal of Applied Science, 2(1), 372375.

Marlinawati, Yusuf, B., \& Alimuddin. (2015). Pemanfaatan Arang Aktif Dari Kulit Durian (Durio zibethinus L) Sebagai Adsorben Ion Logam Kadmium(II). Jurnal Kimia Mulawarman, 13(1), 23-27.

Mutmainnah. (2012). Pembuatan Arang Aktif Tongkol Jagung dan Aplikasinya Pada Pengolahan Minyak Jelantah. Skripsi Sarjana Palu: Universitas Tadulako.

Napitupulu, M., Walanda, D. K., Kusuma, G. Y. N., Basir, M., \& Mahfudz. (2018). Adsorption capacity of biocharcoal from durian barks on cadmium(II) ion. Journal of Surface Science and Technology, 33(1-2), 30-36.

Ni'mah, Y. L., \& Ulfin, I. (2007). Penurunan kadar tembaga dalam larutan dengan menggunakan biomassa bulu ayam. Akta Kimindo, 2(1), 57-66.

Oliveira, E. I. S., Santos, J. B., Gonçalves, A. P. B., Mattedi, S., \& José, N. M. (2016). Characterization of the rambutan peel fiber (nephelium lappaceum) as a lignocellulosic material for technological applications. Chemical Engineering Transactions, 50, 391-396.

Podala, K., Walanda, D. K., \& Napitupulu, M. (2015). Biocharcoal dari kulit kakao (theobroma cacao 1) untuk mengadsorpsi ion logam timbal (Pb). Jurnal Akademika Kimia, 4(3), 136-142.

Pongenda, R. C., Napitupulu, M., \& Walanda, D. K. (2015). Biocharcoal dari biji salak (salacca edulis) sebagai adsorben terhadap ion logam kromium. Jurnal Akademika Kimia, 4(2), 84-90.

Rudin, R. L. (2011). Pembuatan biocharcoal dari kulit pisang kepok untuk penyerapan logam timbal (Pb) dan logam seng $(\mathrm{Zn})$. Skripsi Sarjana Palu: Universitas Tadulako.

Suryati, T., \& Priyanto, B. (2003). Eliminasi logam berat kadmium dalam air limbah menggunakan tanaman air. Jurnal Teknologi Lingkungan, 4(3), 143-147. 
Susilawati, N. E., Walanda, D. K., \& Napitupulu, M. (2015). Biocharcoal dari serbuk gergaji kayu cempaka (elmerrillia ovalis miq) serta daya adsorpsinya pada zink dan tembaga. Jurnal Akademika Kimia, 4(2), 71-77.

Talunoe, O. (2014). Pemanfaatan arang aktif kulit kacang tanah sebagai adsorben besi ( $\mathrm{Fe}$ ) pada Air sumur di desa Pendolo Kecamatan Pamona Selatan Kabupaten Poso. Skripsi Sarjana Palu: Universitas Tadulako.

Tong, X., Li, J., Yuan, J., \& Xu, R. (2011). Adsorption of $\mathrm{Cu}$ (II) by biochars generated from three crop straws. Chemical Engineering Journal, $172(2-3), 828-834$.
Wahyuni, S., Ningsih, P., \& Ratman. (2015). Pemanfaatan arang aktif biji kapok (ceiba pentandra l.) sebagai adsorben logam timbal (Pb). Jurnal Akademika Kimia, 5(4), 191-196.

Widihati, I. A. G., Suastuti, N. G. A. M. D. A., \& Nirmalasari, M. A. Y. (2012). Studi kinetika adsorpsi larutan ion logam kromium (cr) menggunakan arang batang pisang (Musa paradisiaca). Jurnal Kimia, 6(1), 8-16.

Widowati, W., Sastino, A., \& Jusuf, R. (2008). Efek toksik logam. Yogyakarta: Andi Publiser. 